\title{
Penerapan Bermain Bebas Dalam Mengembangkan Kemampuan Sosial Anak Usia 5-6 Tahun Di Tk.Mekarjaya Kec.Sepatan Kab.Tangerang
}

\author{
Syifa Urpiah ${ }^{1}$, Titi Rachmi² \\ 1,2 Program Studi Pendidikan Guru Pendidikan Anak Usia Dini, Fakultas \\ Keguruan Dan Ilmu Pendidikan, Universitas Muhammadiyah Tangerang.

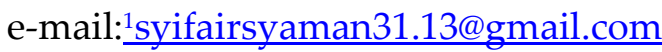

\begin{abstract}
Abstrak
Penelitian ini bertujuan untuk mengetahui penerapan bermain bebas dalam mengembangkan kemampuan sosial anak usia 5-6 tahun adalah anak dapat interaksi dengan teman sebaya, dapat berinteraksi dengan orang dewasa, dapat memecahkan konflik, lebih percaya diri, punya banyak teman, dapat interaksi dan saling membantu, dapat berbagi, anak dapat pola bergiliran, dapat menggunakan dan menjaga benda-benda dan lingkugan secara tepat, dapat perduli terhadap orang lain seperti memahami dan menerima pebedaan individu, dapat memahami masalah multibudaya. Pada dua subjek penelitian didapat ada perbedaan antara MSN dan MAD pada kemampuan sosial anak usia 5-6 tahun, Penelitian ini termasuk jenis penelitian kualitatif deskriptif yang mngacu kepada hasil observasi dan wawancara. Pada penelitian ini ditemukan dua sumber data yaitu MSN dan MAD. Teknik pengumpulan data dilakukan dengan menggunakan catatan wawancara dan catatan observasi. Penelitian ini juga didukung oleh dokumentasi yang memadai. Hasil data disajikan secara narasi deskriptif. Hasil penelitian menunjukan bahwa penerapan bermain bebas dalam mengembangkan kemampuan sosial anak usia 5-6 tahun. Berdasaran hasil temuan peneliti yang didapatkan, maka penelitian ini layak digunakan oleh masyarakat luas dan dapat dikembangkan untuk penelitian yang lebih lanjut.
\end{abstract}

Kata kunci : Bermain Bebas, Kemampuan Sosial, Anak Usia 5-6 tahun

\section{Pengantar}

Undang-Undang RI Nomor 20 Tahun 2003 Tentang Sistem Pendidikan

Nasional Pasal 1 Ayat 14, Pendidikan Anak Usia Dini adalah upaya pembinaan yang ditunjukan kepada anak sejak lahir sampai dengan usia enam tahun yang dilakukan melalui pemberian rangsangan pendidikan untuk membantu 
"Ceria"

Jurnal Program Studi Pendidikan Anak Usia Dini

pertumbuhan dan perkembangan jasmani dan rohani agar anak memiliki kesiapan memasuki pendidikan lebih lanjut. Rangsangan yang diberikan kepada anak pun harus sesuai dengan pertumbuhan dan perkembangan anak, ketika rangsangan yang diberikan sudah sesuai dengan tingkat kebutuhan anak itu akan membantu anak dalam kehidupan sehari-harinya dan tingkat perkembangannya akan sesuai dengan usia mereka.

Rangsangan tersebut tidak hanya untuk kesiapan memasuki pendidikan lebih lanjut saja, tetapi untuk menghadapi masa dimana anak-anak sudah masuk kelingkungan masyarakat yang beragam jenis suku bangsa yang berbeda dan mengajarkan anak bahwa lingkungan tidak hanya sebatas keluarga atau sekolah tetapi ada yang lebih luas lagi dibandingkan itu. Selain itu ketika anak sudah terbiasa dengan lingkungan sosial itu akan terbawa saat mereka dewasa dan itu sangat membantu mereka nantinya.

Bermain bebas bisa membantu anak dalam kemampuan sosialnya ketika anak masih kurang bersosialisasi dengan teman-temannya, karena bermain bisa menjadi wadah berkumpul yang baik untuk anak melalukan interaksi dengan yang lainnya. Bermain pun bisa menjadi solusi yang menyenangkan untuk melakukan interaksi dan kerjasama selain itu menumbuhkan rasa perduli terhadap yang lain, mereka pun bisa bereksplorasi dan mendapatkan pengetahuan yang baru pula. Interaksi yang dibangun sejak kecil dapat membantu anak menumbuhkan rasa percaya dirinya didepan orang lain.

Menurut Bruno, perkembangan sosial merupakan proses pembentukan sosial (sosial self), yakni pribadi dalam keluarga, budaya, bangsa, negara Djaali (2008,h.49). Maka disini anak masih harus membutuhkan dorongan agar pembentukan sosialnya berkembang dengan baik. Karena motivasi dari orangorang terdekat seperti orang tua dirumah dan guru disekolah itu penting untuk kemajuan anak bersama. Selain motivasi yang dibutuhkan anak kepercayaan diri anak juga harus dibangun karena dibutuhkan untuk anak siap berada dilingkungan masyarakat. 
"Ceria"

\section{Jurnal Program Studi Pendidikan Anak Usia Dini}

Anak-anak di tahap perkembangan ini biasanya memiliki interaksi dengan lingkungan sosial yang lebih luas secara intens. Anak-anak sudah memiliki keinginan untuk berinteraksi dengan teman-temannya. Luasnya interaksi dengan lingkungan sosial seperti dengan teman-teman dan guru tentu berpengaruh terhadap perkembangan kepribadiannya. Contoh, anak-anak ditaman kanakkanak sudah memiliki kecenderungan untuk berkelompok dengan temantemannya Rozi dan Kinasih (2015,h.33). Pada hakikatnya anak atau orang dewasa adalah makhluk sosial dan mereka hidup berkelompok dalam suatu lingkungan masyarakat, dan itu tidak akan terpisahkan dalam kehidupan sosial.

Bermain bagi anak usia dini sangat penting. Sebab melalui bermainlah anak mengalami proses pembelajaran. Selain itu, salah satu karakteristik anak usia dini ialah suka bermain. Artinya bermain sudah menjadi kebutuhan alamiah setiap anak yang harus dipenuhi.

Apabila tidak dipenuhi, maka akan dapat mengganggu proses perkembangan anak itu sendiri Fadillah (2017,h.11). Tidak salah bahwa motivasi dari guru untuk anak bermain bersama teman itu memang dibutuhkan untuk perkembangan anak, selain itu pembelajaran untuk anak itu banyak ketika ia bermain bersama teman yang lain yaitu untuk lebih bersabar, saling bergantian, dan saling menghormati atu sama lain.

Berbicara masalah tujuan bermain anak usia dini tidak bisa terlepas dari psikologi atau kepribadian anak. Sebab bermain merupakan cerminan dari kebutuhan dasar anak yang mesti dikembangkan. Tujuan bermain dimaksudkan untuk mengetahui peranan bermain dalam perkembangan anak usia dini Fadillah $(2017$, h.8). Maka apa yang telah disampaikan diatas memang benar adanya bahwa bermain mempunyai peranan yang penting bagi perkembangan anak, karna selain menyenangkan bermain bisa mengembangkan kemampuan sosial anak dan kemampuan-kemampuan lain yang ada didalam diri anak.

Dengan demikian peranan bermain bebas dalam mengembangkan kemampuan sosial anak usia 5-6 tahun sangat membatu, karena dengan bermain 
"Ceria"

\section{Jurnal Program Studi Pendidikan Anak Usia Dini}

anak mampu berinteraksi dengan teman sebayanya, mengalami psoes pembelajaran, percaya diri serta perkembangan-perkembangan anak yang lainnya akan mengikuti dengan anak merasa senang saat melakukan kegiatan bermain tersebut.

\section{Metode}

Metode penelitian yang digunakan dalam penelitian ini adalah penelitian Kualitatif, dengan subjek penelitian 2 orang anak yaitu MSN dan MAD di Tk.Mekarjaya Kab. Tangerang. Putra dan Dwilestari (2012, h.127) Penelitian kualitatif mesti melibatkan diri penuh ketika meneliti.

Sebab dialah instrumen utama penelitian. Karena hanya peneliti yang bisa berempati, membangun interaksi yang manusiawi, menangkap dan memahami perspektif anak. Adapun jenis metode penelitian ini menggunakan studi kasus karena diambil dari masalah yang terjadi dalam suatu lembaga sekolah dan meneliti dalam proses pembelajaran maka strategi yang digunakan peneliti berupa studi kasus.

Adapun langkah-langkah yang dilakukan dalam penelitian ini adalah, Tahap awal dengan melakukan observasi berupa pengamatan dengan menggunakan catatan lapangan untuk mengamati dan mencatat siswa-siswi Tk B (5-6 tahun) di Tk.Mekarjaya Sepatan Tangerang, Tahap kedua yaitu dengan menyusun rancangan lembar daftar pertanyaan berupa wawancara dan cacatan lapangan, Tahap ketiga dengan mendokumentasikan kegiatan dan pembelajaran dikelas, Tahap keempat yaitu memberikan uraian atau mendeskripsikan semua tentang pengumpulan data dan pengolahan analisis data.

\section{Hasil Dan Pembahasan}

Penelitian Kualitatif di Tk. Mekarjaya Kec.Sepatan Kab.Tangerang, Berdasarkan temuan penelitian mengenai Penerapan Bermain Bebas Dalam Mengembangkan Kemampuan Sosial Anak Usia 5-6 Tahun, peneliti akan berusaha memaparkan secara bertahap. Pertama akan memaparkan tentang 
"Ceria"

Jurnal Program Studi Pendidikan Anak Usia Dini

kemampuan sosial anak disekolah dan yang kedua memaparkan kemampuan sosial anak dirumah.

Dalam penelitian telah ditemukan bagaimana kemampuan sosial anak yang teridentifikasi penerapan bermain bebas. Berdasarkan penelitian yang dilakukan dari semua anak yang ada di TK, peneliti telah mendapatkan hasil berdasarkan kemampuan sosial anak di Tk. Mekarjaya dari mewawancarai beberapa sumber data, sumber data yang pertama adalah anak usia 6 tahun bernama MSN. Sumber data yang kedua adalah MAD anak usia 6 tahun.

\section{Hasil Wawancara dan Observasi Kemampuan Sosial Anak disekolah}

Pada sumber data yang pertama peneliti melakukan wawancara dengan guru dan kepala sekolah untuk tau bagaimana interaksi sosial MSN didalam kelas, dari penemuan-penemuan dan observasi dapat disimpukan bahwa anak masih kurang berinteraksi dengan temannya saat disekolah karena anak lebih suka atau banyak menyendiri dibandindang berinteraksi dengan temannya namun kepada guru dan kepala sekolah anak baik dan sopan, untuk percaya diri anak pun masih perlu motivasi, stimulus atau dorongan dari guru dan kepala sekolahnya, MSN untuk berbagi ia sangat baik, dan untuk menyelesaikan konflik dan menjaga mainnya anak belum bisa. Seperti yang terlihat pada gambar diatas anak hanya duduk diam sendirian tanpa ada interaksi dengan yang lainnya.

Selanjutnya peneliti mewawancarai guru dan kepala sekolah tentang bagaimana interaksi sosial MAD saat didalam kelas, dari pemaparan yang ada dilapangan dan wawancara bahwa MAD sudah mampu bersosialisai dan interaksi dengan teman sebayanya dengan baik, namun untuk percaya dirinya anak masih perlu motivasi dari guru dan kepala sekolah saat di sekolah, MAD juga adalah anak yang baik, sopan dan mau berbagi dengan temannya.

Dari pemaparan kedua subjek yang peneliti temukan dilapangan dan wawancara kepada guru dan kepala sekolah ditemukan bahwa MAD dan MSN masih perlu motivasi untuk mengembangkan kemampuannya 
"Ceria"

\section{Jurnal Program Studi Pendidikan Anak Usia Dini}

dalam interaksi sosial, serta percaya diri anak, sedangkan untuk MAD sudah ada kemauan untuk interaksi dan bermain dengan teman, namun untuk MSN masih perlu bantuan dan bimbingan untuk anak mau bersosialisai dan interaksi dengan temannya saat bermain, dan keduanya adalah anak yang baik dan sopan serta mau berbagi dengan temannya.

\section{Hasil Wawancara dan Observasi Kemampuan Sosial Anak dirumah}

Pada wawancara ibu dan kakak dirumah MSN didapatkan bahwa interaksi anak berada dalam lingkungan rumah, dari pemaparan dapat temukan bahwa interaksi anak terbilang hanya dengan orang-orang yang ada didalam rumah sedangkan untuk luar rumah anak bermain dengan teman kakaknya yang sudah besar,maka didapat bahwa saat anak berada dilingkungan sekolah atau lingkungan luar yang lain anak harus beradaptasi dengan lingkungan baru, dan interaksi anak masih tergolong sangat minim dan percaya diri anak pun harus dibangun untuk anak beradaptasi dan interaksi dengan lingungan sosial untuk menumbuhkan rasa percaya diri anak dalam kemampuannya bersosialisasi.

Selanjutnya peneliti mewawancarai ibu dan kakak MAD tentang pola interaksi MAD dirumah, dari pemaparan didapat bahwa ibu dan kakaknya mempunyai kekhawatiran yang sama kalau MAD takut kenapakenapa, dan interaksi anak dengan lingkungan rumah baik dan ada interaksi dengan teman dirumahnya meskipun ada jam-jam yang sudah ditentukan dari orang tua.

Dari pemaparan wawancara dan observasi dari dua subjek diatas dapat disimpulkan bahwa ada perbedaan saat dirumah dan disekolah seperti MSN saat anak dirumah anak terlihat sangat aktif dan bersosialisasi dengan lingkungan rumahnya sedangkan saat disekolah anak terlihat diam, seperti tidak percaya diri dan membutuhkan adaptasi dengan lingkungan sekolah, sedangkan MAD disekolah dan dirumah terlihat sama saja namun MAD pun masih perlu dibangun rasa percaya dirinya seperti MSN, dan seperti dilihat dari pemaparan diatas orang tua 
"Ceria"

Jurnal Program Studi Pendidikan Anak Usia Dini

MAD dan MSN mempunyai khawatir kepada anaknya ketika anak bermain diluar dari pengawasan mereka meskipun anak berada dalam lingkungan luar rumahya, untuk menjaga mainnya anak-anak masih kurang dalam menjaga mainannya dan rasa percaya diri anak masih harus dibangun serta motivasi-motivasi anak untuk bergabung dengan lingungan sosial juga harus dibangun untuk anak mampu mengembangkan kemampuan sosialnya dengan baik, mereka adalah anak baik, sopan dan mau berbagi meskipun anak belum terlibat dalam interaksi sosial yang intens.

Hal ini sesuai dengan penelitin yang dilakukan mahasiswa Kharida dalam skripsinya yang berjudul Shaleha“Peranan Metode Bermain Peran Dalam Mengembangkan Sosial Emosional Anak Usia Dini “ tahun 2017 dari Universitas Negeri Medan. Berdasarkan hasil pembahasan maka dapat diambil kesimpulan bahwa Metode bermain peran (role playing) merupakan salah satu metode yang dapat mengembangkan sosial, emosional anak usia dini, karena dengan Bermain peran (role playing) membantu anak mengeluarkan emosinya yang terpendam karena tekanan sosial. bermain peran dapat menjadi wahana bagi pengembangan sosial, emosional. Penelitian ini mempunyai tujuan yang sama dalam mengembangkan kemampuan sosial anak lewat bermain, karena baik dengan bermain peran atau bermain bebas akan membantu anak dalam kemampuan anak yang lainnya terlebih dalam interaksi sosialnya.

\section{Kesimpulan dan Saran}

Berdasarkan hasil penelitian kualitatif dengan tekhnik observasi, wawancara, dan dokumentasi tentang bermain bebas dalam mengembangkan kemampuan sosial anak usia 5-6 tahun dapat diambil beberapa kesimpulan.

Kesimpulan tersebut dipaparkan sebagai berikut, Kemampuan sosial anak adalah sesuatu yang penting untuk keberlangsungannya dimasa depan, karena kemampuan sosial membantu anak untuk menjadi seseorang belajar untuk 
"Ceria"

\section{Jurnal Program Studi Pendidikan Anak Usia Dini}

memahami bahwa didunia yang sebesar ini tidak hanya ada orang tua atau keluarga besarnya saja, tetapi masih banyak orang lain yang berbeda-beda dan sama sepertinya, Ketika anak terlihat interaksi sosialnya kurang dengan lingkungan orang tua, keluarga serta guru atau orang yang ada dilingkungannya ikut membantu dengan memotivasi anak memberikan dorongan yang baik agar anak mampu bertinteraksi dan bergabung dengan lingkungan masyarakat lainnya, Bermain sangat penting dan sangat dibutuhkan untuk anak mengolah emosi serta kemampuan yang dimiliki masing-masing anak, karena bermain menumbuhkan dan mengembangkan berbagai aspek yang sangat penting dalam perkembangannya, Ketika ada orang tua melarang anak untuk bermain karena berbagai alasan, lebih baik baik orang tua ikut peran serta dalam bermain atau mengawasi anak agar apa yang orang tua khawatirkan tidak terjai kepada anak, Bermain adalah suatu wadah yang mengembangkan kemampuan terutama kemampuan sosial anak, karena saat itu anak mulai mengenal interaksi dan berhadapan atau beramain dengan orang baru yang mereka kenal selain orang tua atau keluarga besarnya.

\section{Daftar Acuan}

Djaali (2008).Psikologi Pendidikan.Jakarta:PT.Bumi Aksara Fadlillah (2017). Bermain \& Permainan. Jakarta:Kencana

Peraturan Mentri Pendidikan dan Kebudayaan Republik Indonesia, Nomor 137 Tahun 2014 Tentang Standar Pendidikan Anak Usia Dini

Shaleha, Kharida (2017) "Peranan Metode Bermain Peran Dalam Mengembangkan Sosial Emosional Anak Usia Dini "http://www.google.com/search?hl=id\&source=hp\&biw=\&bih=\&q=perana $\underline{\text { n+bermain+peran+dalam+mengemangkan+kemampuan+sosial\&btnG=Pen }}$ elusuran+Google\&gbv $=2$ ( diakses 25 November 2018 )

Putra, Nusa dan Dwilestari, Ninin (2012). Penelitian Kualitatif PAUD. Jakarta:PT 